\title{
Invited into every school and home
}

In Post $\mathcal{E}$ Mail, Sir Randolph Quirk replies to Braj Kachru's 'Liberation linguistics and the Quirk Concern' (ET 25, Jan 91), itself a response to Sir Randolph's 'Language varieties and standard language' (ET21, Jan 90). In the same post-bag, Philip Tregidgo makes some pointed comments on the styles both linguists use to address their topics and readers. These letters make a valuable accompaniment to this issue's opening article, a meditation by John Algeo on the varieties of English that highlights the fictive nature of such concepts as 'language', 'variety', 'English', 'British English', and 'American English'. Further comments are welcome on articles and letters alike.

Comment is also sought on the second feature, 'Bilingual Denmark', in which Paul Christophersen considers the implications of a national educational policy that seeks to make every citizen bilingual in Danish and English. The situation he describes is probably not confined to the Danes, and the impact of policies of this kind is highly relevant to the Quirk/Kachru debate: sooner or later we must ask and answer such questions as Is there now a distinctive Danish English, just as there has for many years been a distinctive Irish or South African English?

For some years it has seemed to me that north-western Europe, the home of the Germanic languages, is particularly vulnerable to the inroads of English as a 'partner language' to the various ancient national tongues. All have a full panoply of educational, publishing and other institutions to define and sustain their standard forms, yet they may find that such long-standing strengths are not enough when bilingualism really jells. English, in effect, could end up calling the tune from Lapland to the Rhine.

I therefore invite readers in Norway, Sweden, the Netherlands, Germany, and Austria (at least) to comment on Christophersen especially as regards the language situation in their own countries - and also invite Danish readers to indicate how they respond to what he has said. Readers elsewhere may of course see parallels to what is happening or could happen in their parts of the world - as and when English is invited into every school and home in the land.

Tom McArthur

The editorial policy of English Today is to provide a focus or forum for all sorts of news and opinion from around the world. The points of view of individual writers are as a consequence their own, and do not reflect the opinion of the editorial board. In addition, wherever feasible, ET generally leaves unchanged the orthography (normally British or American) and the usage of individual contributors, although the editorial style of the joumal itself is that of Cambridge University Press.

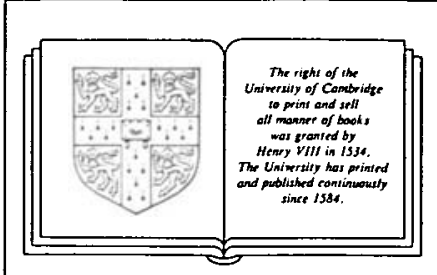

(C) Cambridge University Press 1991 No contents may be reproduced by any means without the permission of Cambridge University Press.

ISBN 0521422892

English Today (ISSN 0266-0784) is a quarterly.

\section{Publisher:}

Cambridge University Press, Edinburgh Building, Shaftesbury

Road, Cambridge CB2 2RU.

Telephone (0223) 312393

Subscriptions: the current annual subscription price for four issues for libraries and institutions is $\Sigma 38$ outside North America; ₹18 for individuals; $\mathrm{E} 14$ for students and the retired; airmail 19 per year extra. Apply to Jane Crossland at the above address.

Advertising Sales: write to Anita Fern at the above address.

\section{USA AND CANADA:}

Publisher:

Cambridge University Press, 40 West 20th Street, New York, NY 10011-4211.

Telephone (212) 9243900.

Subscriptions: the current annual subscription price in USA and

Canada for libraries and institutions is $\$ 63 ; \$ 29$ for individuals; $\$ 20$ for students and the retired. Copies are air-freighted to New York to arrive with minimum delay. Apply to Lynda DiCaprio at the above address.

Advertising Sales: write to Michelle Alumkal at the above address.

Second class postage paid at New York, NY and at additional mailing offices.

POSTMASTER: send address changes in USA and Canada to English Today, Cambridge University Press, 110 Midland Avenue, Port Chester, New York, NY 10573-9864.

Letters to the Editor: write to Dr Tom McArthur, Editor, English Today, 22-23 Ventress Farm Court, Cherry Hinton Road, Cambridge CB1 4HD, UK.

Typeset by Goodfellow \& Egan. Printed in Great Britain at the University Press, Cambridge 